\title{
Ground Water Protection Management Program Plan
}

February 1994 


\section{INTENDED FOR PUBLIC RELEASE}

This report has been reproduced from the best available copy. Available in paper copy and microfiche.

Number of pages in this report: 36

DOE and DOE contractors can obtain copies of this report from:

Office of Scientific and Technical Information

P.O. Box 62

Oak Ridge, TN 37831

(615) 576-8401

This report is publicly available from:

National Technical Information Service

Department of Commerce

5285 Port Royal Road

Springfield, VA 22161

(703) 487-4650 
URANIUM MILL TAILINGS REMEDIAL ACTION PROJECT

GROUND WATER PROTECTION MANAGEMENT PROGRAM PLAN

SIGNATURE PAGE

Reviewed By:

Reviewed By:

Concurrence By:

Approved By:

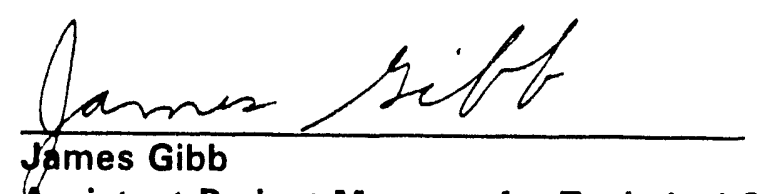

Assistant Project Manager for Technical Services UMTRA Technical Assistance Contractor

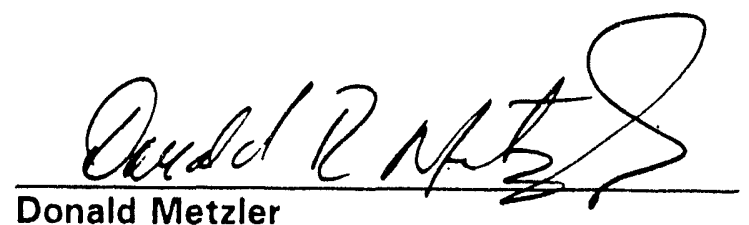

Donald Metzler

Groundwater \& Geohydrology Manager DOE UMTRA Project Office

Bennett Young

Environment, Safety, \& Health Manager DOE UMTRA Project Office
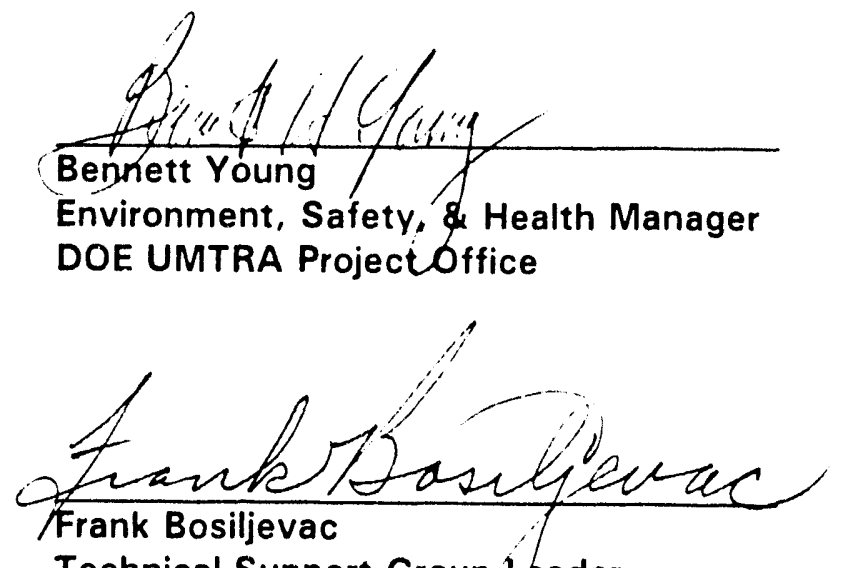

Technical Support Group Leader DOE UMTRA Project Office $\frac{12-10-93}{\text { Date }}$
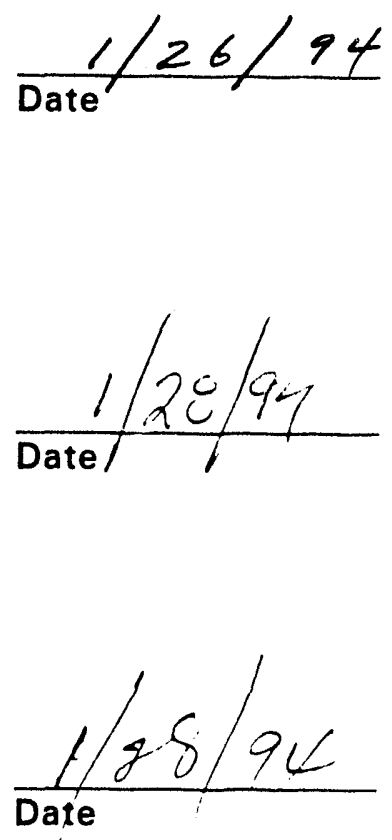


\title{
GROUND WATER PROTECTION MANAGEMENT PROGRAM PLAN
}

\author{
February 1994
}

\section{DISCLAIMER}

This report was prepared as an account of work sponsored by an agency of the United States Government. Neither the United States Government nor any agency thereof, nor any of their employees, makes any warranty, express or implied, or assumes any legal liability or responsibility for the accuracy, completeness, or usefulness of any information, apparatus, product, or process disclosed, or represents that its use would not infringe privately owned rights. Reference herein to any specific commercial product, process, or service by trade name, trademark, manufacturer, or otherwise does not necessarily constitute or imply its endorsement, recommendation, or favoring by the United States Government or any agency thereof. The views and opinions of authors expressed herein do not necessarily state or reflect those of the United States Government or any agency thereof.

\author{
Prepared for \\ U.S. Department of Energy \\ UMTRA Project Office \\ Albuquerque, New Mexico \\ Prepared by \\ Jacobs Engineering Group Inc. \\ Albuquerque, New Mexico
}




\section{EXECUTIVE SUMMARY}

U.S. Department of Energy (DOE) Order 5400.1 requires the establishment of a ground water protection management program to ensure compliance with DOE requirements and applicable federal, state, and local laws and regulations. The Uranium Mill Tailings Remedial Action (UMTRA) Project Office has prepared this Ground Water Protection Management Program Plan (ground water protection plan) whose scope and detail reflect the program's significance and address the seven activities required in DOE Order 5400.1, Chapter III, for special program planning.

This ground water protection plan highlights the methods designed to preserve, protect, and monitor ground water resources at UMTRA Project processing and disposal sites. The plan includes an overview of the remedial action status at the 24 designated processing sites and identifies technical guidance documents and site-specific documents for the UMTRA Project ground water protection management program. In addition, the plan addresses the general information required to develop a water resources protection strategy at the permanent disposal sites. Finally, the plan describes ongoing activities that are in various stages of development at UMTRA Project sites llong-term care at disposal sites and ground water remediation at processing sites). This plan will be reviewed annually and updated every 3 years in accordance with DOE Order 5400.1 .

Information concerning UMTRA Project activities to preserve, protect, and monitor ground water resources, along with other characterization activities, is summarized in the UMTRA Project Environmental Protection Implementation Plan and the UMTRA Project Environmental Monitoring Plan. Additional information is available from UMTRA Project guidance documents and site-specific documents. 
TABLE OF CONTENTS

Section

Page

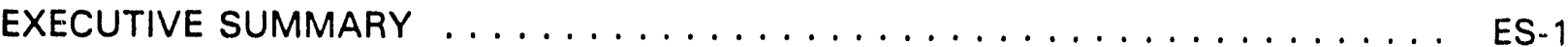

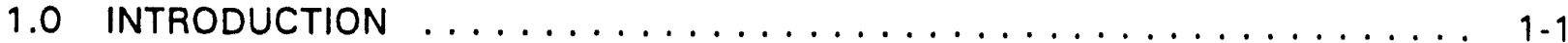

1.1 Project overview ........................... 1-1

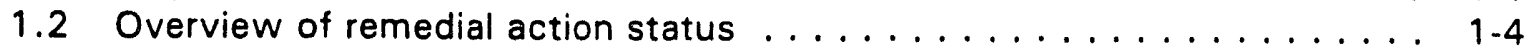

1.3 Applicable environmental protection laws and regulations . . . . . . . 1.4

1.4 Technical planning documents ................... 1-5

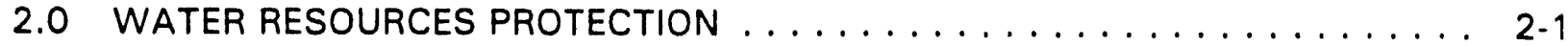

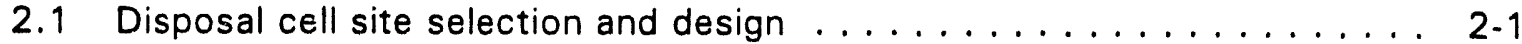

2.2 Hydrogeologic characterization .................... 2-1

2.3 Disposal and control of residual radioactive materials . . . . . . . . . . 2-3

2.3.1 Ground water protection strategy ............... 2-3

2.3.2 Performance assessment ................. 2.3

2.3.3 Closure performance assessment ................ 2-3

2.3.4 Ground water monitoring and corrective action planning . . . . . . 2-4

2.4 Ground water cleanup ......................... 2.4

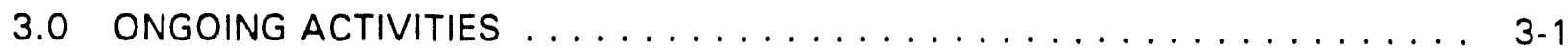

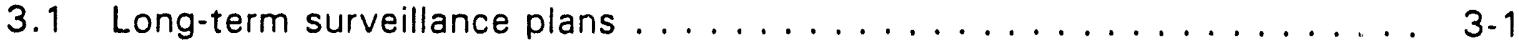

3.2 Ground water remediation activities ............... 3.2

4.0 LIST OF CONTRIBUTORS $\ldots \ldots \ldots \ldots \ldots \ldots \ldots \ldots \ldots \ldots \ldots \ldots$

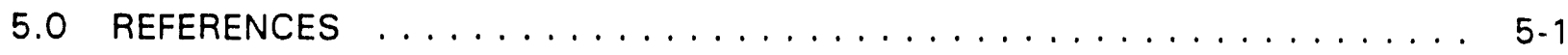




\section{LIST OF FIGURES}

\section{Figure}

\section{Page}

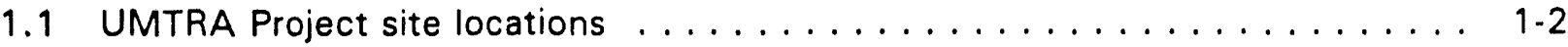


LIST OF ACRONYMS AND ABBREVIATIONS

Acronym Definition

DOE

EPA

LTSP

NEPA

NRC

POC

QAPP

RAP

RRM

TAD

TAGR

UMTRA

UMTRCA

WSAP

U.S. Department of Energy

U.S. Environmental Protection Agency

long-term surveillance plan

National Environmental Policy Act

U.S. Nuclear Regulatory Commission

point of compliance

quality assurance program plan

remedial action plan

residual radioactive materials

Technical Approach Document

Technical Approach to Ground Water Restoration

Uranium Mill Tailings Remedial Action

Uranium Mill Tailings Radiation Control Act

water sampling and analysis plan 


\subsection{INTRODUCTION}

U.S. Department of Energy (DOE) Order 5400.1 requires the establishment of a ground water protection management program to ensure compliance with all DOE requirements and applicable environmental protection laws and regulations. A ground water protection management program has been developed for the Uranium Mill Tailings Remedial Action (UMTRA) Project and has been implemented by the UMTRA Project Technical Assistance Contractor.

This ground water protection plan addresses, as appropriate, the following seven activities in DOE Order 5400.1, Chapter III: 1) documentation of the ground water regime with respect to quantity and quality, 2) design and implementation of a ground water monitoring program to support resource management and comply with applicable environmental laws and regulations, 3) a management program for ground water protection and remediation, 4) identification of areas that may be contaminated with hazardous substances, 5) strategies for controlling sources of those hazardous constituents, 6) development of remedial action plans (RAP) that are consistent with the Uranium Mill Tailings Radiation Control Act of 1978 (UMTRCA), 42 U.S.C. $\$ 7901$ et seq.,

7) decontamination and decommissioning, and other remedial programs contained in DOE directives.

This ground water protection plan is a component of the UMTRA Project environmental protection program as detailed in the UMTRA Project Environmental Protection Implementation Plan (DOE, 1993a). Other characterization activities are addressed in the UMTRA Project Environmental Monitoring Plan (DOE, 1992a).

\subsection{PROJECT OVERVIEW}

During the 1970s, Congress recognized that residual radioactive materials (RRM) at uranium mill tailings sites may pose a potentially significant radiation health hazard to the public. In 1978, Congress passed the UMTRCA to reduce future potential health hazards to the public and to ensure the future protection of public health and the environment. RRM is defined as radioactive wastes in the form of tailings resulting from the processing of ores for the extraction of uranium and other valuable constituents of the ores, and other radioactive wastes present at or near a processing site that relates to such processing. The UMTRCA authorizes the DOE to perform remedial actions at 24 inactive uranium mill tailings sites and, upon completion of the remedial actions, to care for the permanent disposal sites under a general license issued by the U.S. Nuclear Regulatory Commission (NRC) (Figure 1.1). The DOE established the UMTRA Project to carry out this mission.

The Atomic Energy Act of 1954, 42 U.S.C. \$2011 et seq., as amended by the UMTRCA, authorizes the U.S. Environmental Protection Agency (EPA) to promulgate standards for remedial action and ground water protection at inactive uranium processing sites. The regulations, 40 CFR 192, took effect on March 7 , 1983. However, on January 5, 1985, the ground water protection standards 140 CFR 192.02(a)(2)-(3)) were remanded by the U.S. Court of Appeals for the Tenth Circuit. New ground water protection standards for 40 CFR 192 were proposed on 


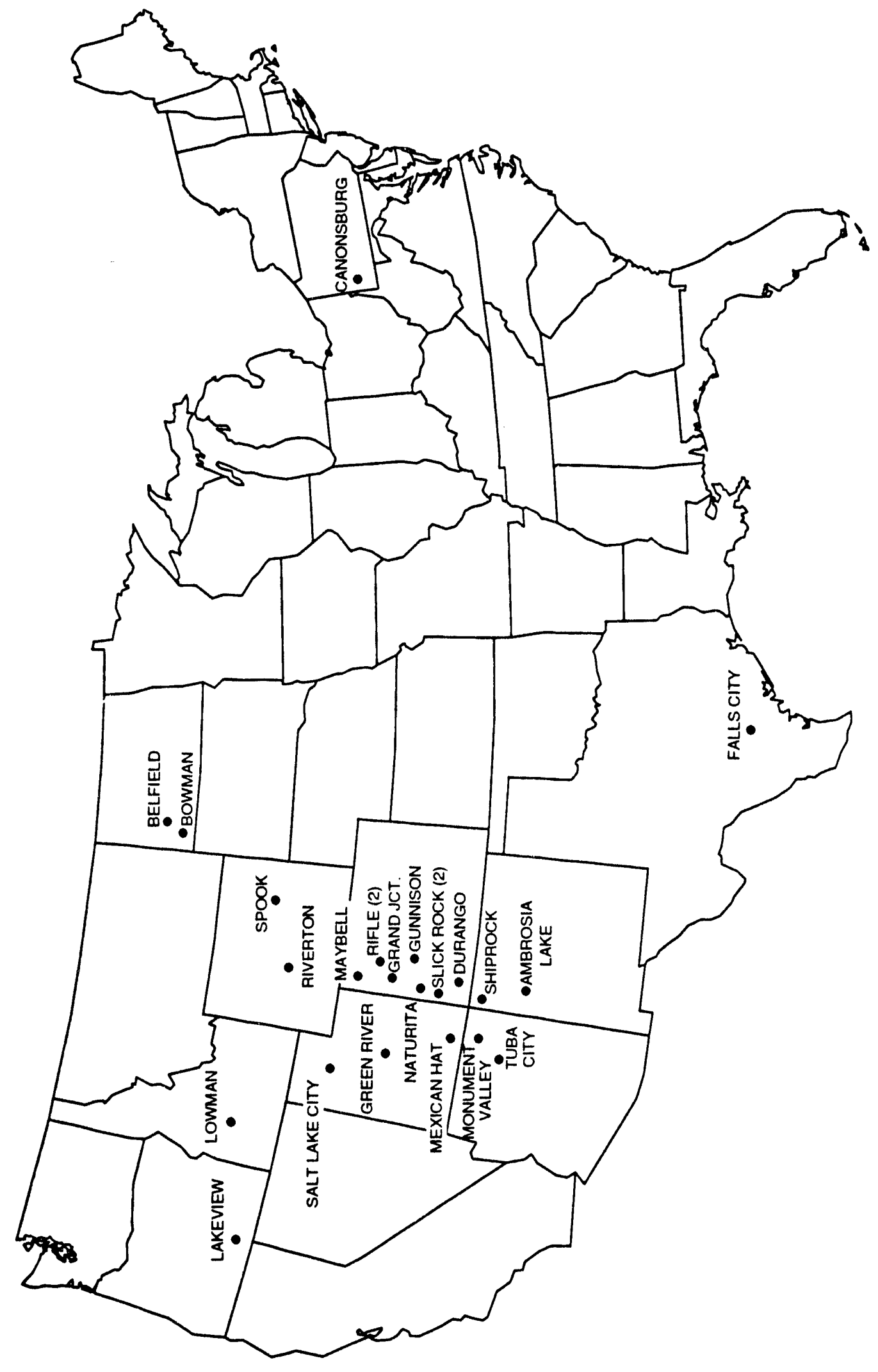

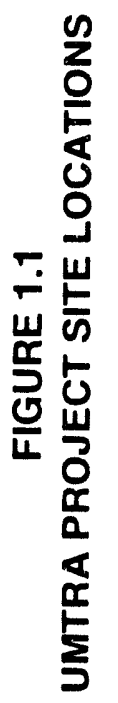


September 24, 1987 (52 FR 36000). The EPA-proposed ground water protection standards establish requirements for the control of contaminants from the RRM into the ground water at disposal sites and for the cleanup of existing ground water contamination at designated processing sites and vicinity property sites. In lieu of final standards, remedial actions with regard to ground water protection are being conducted in accordance with the proposed standards as directed by the UMTRCA.

The UMTRCA allows the DOE to extend without limitation the time frame needed to complete ground water remediation activities required by 40 CFR 192 at the processing sites. However, the DOE must complete all surface remedial action activities, including compliance with the proposed ground water protection standards for the disposal sites, by 1996. After the NRC concurs in the DOE certification that the surface remedial actions are complete, custodial responsibility of the permanent disposal sites will be transferred to the federal government to be cared for under the general license by the DOE or any other federal agency designated by the President.

The standards proposed by the EPA require the DOE to monitor for ground water protection at the permanent disposal sites after the surface remedial actions are completed. This regulatory requirement will be carried out under the long-term surveillance program established in accordance with the NRC regulations for licensing and long-term care (10 CFR 40.27).

The UMTRA Project objective is to stabilize the RRM in permanent disposal facilities in a safe and environmentally responsible manner. In accordance with the UMTRCA, the remedial actions, including ground water protection, undertaken by the UMTRA Project are performed as follows:

- In compliance with the remedial action standards for UMTRA Project sites, issued by the EPA in 40 CFR 192.

- In compliance with the proposed ground water protection standards for UMTRA Project sites (until these standards become final).

- In compliance with the standards for the general license for custody and longterm care of RRM disposal sites, issued by the NRC in 10 CFR 40.27 .

- With the concurrence of the NRC and the full participation and concurrence of the affected states and Indian tribes.

A primary concern of the UMTRA Project is the protection of ground water resources from remedial action activities at processing and disposal sites. In addition, ground water resources need to be protected from residual contamination after the remedial action is completed. Ground water protection is considered in evaluating remedial action alternatives, disposal site selection, and general site activities. Before remedial actions are initiated, the UMTRA Project completes the environmental investigations, documentation, and public reviews required by the National Environmental Policy Act (NEPA), 42 U.S.C. $\$ 4321$ et seq. Assessing the 
potential impacts of UMTRA Project activities on ground water resources is an important part of the Project's NEPA review process.

Recently, the DOE initiated the ground water remediation phase of the UMTRA Project. Current activity focuses on developing management and technical documents for the orderly and systematic planning of remedial action activities. At this time, no active ground water remediation has taken place at UMTRA Project sites, although the need to perform ground water remediation is being assessed at all processing sites.

For further details on the UMTRA Project objective, technical approach for accomplishing the goals, participants' roles and responsibilities, and planning and managerial controls to be used in performing the site work, consult the UMTRA Project Site Management Manual (DOE, 1990a).

\subsection{OVERVIEW OF REMEDIAL ACTION STATUS}

The UMTRA Project began in 1983 and has completed surface remedial action activities and stabilized in permanent disposal facilities the tailings and related RRM at 10 of the 24 designated sites. The completed sites are Canonsburg, Pennsylvania; Durango, Colorado; Green River, Utah; Lakeview, Oregon; Lowman, Idaho; Riverton, Wyoming; Salt Lake City, Utah: Spook, Wyoming; Shiprock, New Mexico; and Tuba City, Arizona.

Currently, surface remedial actions are under way at Ambrosia Lake, New Mexico; Falls City, Texas; Grand Junction, Colorado; Gunnison, Colorado; Mexican Hat, Utah; Monument Valley, Arizona; and two sites in Rifle, Colorado. Characterization, conceptual design, and final design are far advanced at Belfield, North Dakota; Bowman, North Dakota; Maybell, Colorado; Naturita, Colorado; and two sites in Slick Rock, Colorado. Completion of all surface remedial action is currently required by 1996 .

In accordance with the UMTRCA and 40 CFR 192, RAPs are developed for all sites for the disposal and cleanup of RRM. All RAPs require the concurrence of the NRC.

\subsection{APPLICABLE ENVIRONMENTAL PROTECTION LAWS AND REGULATIONS}

The preservation and protection of ground water resources at UMTRA Project sites is guided primarily by the following laws, regulations, and internal DOE policies:

- Atomic Energy Act, 42 U.S.C. $\$ 2011$ et seq.

- UMTRCA, 42 U.S.C. $\$ 7901$ et seq.

- Clean Water Act, 33 U.S.C. \$1251 et seq.

- NEPA, 42 U.S.C. $\$ 4321$ et seq. 
- 40 CFR 192, Subparts A-C, standards for uranium mill tailings at inactive sites.

- 52 FR 36000, proposed ground water protection standards.

- 10 CFR 40.27, general license requirements for RRM disposal sites.

- 10 CFR 1021, DOE NEPA procedures.

- DOE Order 5400.1, general DOE environmental protection program requirements.

- DOE Order 5440.1E, DOE NEPA compliance program.

- Applicable state and local laws and regulations.

\subsection{TECHNICAL PLANNING DOCUMENTS}

The technical documents related to ground water protection at UMTRA Project sites are identified below. The documents are available through the UMTRA Project Office. Also listed are the types of site-specific documents produced for each site. Complete references for the technical documents and current versions of sitespecific documents are included in Section 4.0, References.

\section{Technical documents}

- UMTRA Project Environmental Protection Implementation Plan (DOE, 1993a). Describes the UMTRA Project environmental protection program for the implementation of DOE Order 5400.1.

- UMTRA Project Environmental Monitoring Plan (DOE, 1992a). Describes UMTRA Project environmental monitoring programs and includes a detailed plan for ground water monitoring.

- Plan for Implementing EPA Standards for UMTRA Project Sites (DOE, 1984). Presents the UMTRA Project procedures, testing, and evaluation criteria that shall be followed in planning for the impiementation of the EPA standards.

- UMTRA Project Site Management Manual (DOE, 1990a). Documents the organizational and technical approach used to manage the activities required to stabilize and control the UMTRA Project sites.

- UMTRA Project Office Quality Assurance Program Plan (OAPP) (DOE, 1993b). Establishes the guidelines for UMTRA Project participants' quality assurance programs.

- UMTRA Project Environmental, Safety, and Health Plan (DOE, 1992b). Identifies the basic federal environmental, safety, and health standards and DOE requirements applicable to the UMTRA Project. 
- Guidance for Implementing the UMTRA Project Long-term Surveillance Program (DOE, 1992c). Establishes the procedures to be used to develop long-term surveillance plans, including ground water monitoring, for disposal sites after completion of remedial action.

- Alternate Site Selection Process for UMTRA Project Sites (DOE, 1988a). Describes the procedures to be used by the UMTRA Project Office in conjunction with the affected state or Indian tribe to select and agree mutually on an alternate site for off-site disposal.

- Technical Approach Document (TAD) (DOE, 1989a). Describes the general technical approaches for site characterization, disposal cell design, disposal cell performance assessments, and development of water resources protection strategies for demonstrating compliance with the EPA ground water protection standards.

- Regulatory Alternatives for Ground Water Compliance for the U.S. Department of Energy's UMTRA Project (DOE, 1989b). Defines, describes, and provides guidance for compliance with proposed ground water standards.

- Requirements for Quality Control of Analytical Data (DOE, 1990b). Defines quality control requirements and data validation guidelines for analytical data.

- Quality Assurance Implementation Plan (working draft). Identifies the organizations involved with ground water restoration and describes their operational, field, laboratory, and quality assurance responsibilities. Its purpose is to ensure that information collected and used for environmental restoration is of the quality needed to achieve the project goal of ground water restoration.

- Technical Approach to Groundwater Restoration (TAGR) (DOE, 1993c). Describes the technical approach for ground water restoration and discusses conceptual modeling of the site, evaluation of applicable ground water restoration technologies, selection of the preferred alternative, remedial design, and remedial action.

- Guidance Document for Preparing Water Sampling and Analysis Plans for UMTRA Sites, (DOE, 1993d). Provides a consistent technical approach for water sampling and analysis activities at UMTRA Project sites.

- Albuquerque Operations Manual. Jacobs Engineering Group Inc. Specifies or describes how activities are to be performed. Includes procedures on methods to be employed, equipment or materials to be used, and the sequence of operations. The procedures create traceability and consistency in data acquisition, analysis, and support activities. 


\section{Site-specific documents}

- Comparative analysis of disposal site alternatives reports. Provide the basis for agreement with the affected state or Indian tribe on a preferred alternative for site remedial action and with the NRC that the preferred alternative will meet the EPA standards.

- Site NEPA compliance documents. Include environmental assessments or environmental impact statements, findings of no significant impact, records of decision, and other documents required to comply with the NEPA.

- Remedial action selection reports. Summarize the detailed site characterization, design, and water resources protection information that is provided in the RAPs.

- Remedial action plans (RAP). Incorporate site characterization data, identify the series of site activities and the design required to implement the long-term stabilization and coritrol of the RRM for a site, and document the disposal cell design and ground water protection strategy required to demonstrate compliance with the EPA standards.

- Water sampling and analysis plans (WSAP). Provide the annual basis for ground water and surface water sampling at UMTRA Project processing and disposal sites by identifying and justifying the sampling locations, analytical parameters, detection limits, and sampling frequencies.

- Long-term surveillance plans (LTSP). Describe the surveillance and monitoring requirements for the disposal site after remedial actions have been completed and provide the basis for obtaining the site license.

- Special study reports. Present the findings, conclusions, and recommendations on selected topics identified by the UMTRA Project manager to assist in the performance of site planning and remedial actions.

- Baseline risk assessments. Indicate the degree of potential site-related risk to human health and the environment and will be used in part to determine the need for and extent of ground water remediation required at each processing site. 


\subsection{WATER RESOURCES PROTECTION}

This section summarizes the DOE strategy for complying with the proposed ground water protection standards (52 FR 36000). It describes the general technical approach for site characterization, methods for developing the ground water compliance strategy, and methods for evaluating whether the proposed remedial action will meet the proposed standards. The TAD (DOE, 1989a), TAGR (DOE, 1993c), and site-specific RAPs contain further details on the DOE strategy for complying with the EPA standards.

\subsection{DISPOSAL CELL SITE SELECTION AND DESIGN}

RRM from UMTRA Project sites are stabilized either on the site, in place, oi at an alternate site. The site is selected in accordance with procedures described in the Alternate Site Selection Process document (DOE, 1988a). Evaluation criteria include identification of site-specific hazards, risk assessment, technical feasibility, and cost-effectiveness. Disposal cell design is a complex process and is based on consideration of many factors. To ensure that all aspects of a design are considered, a remedial action plan checklist is completed (Table 2.2, DOE, 1989a). Items for consideration related to hydrogeologic conditions at each site include background ground water quality, presence and movement of contaminant plumes and discharge to surface water, prediction of effects of remedial action on ground water, and impacts on beneficial use of ground water. Disposal cell design features are incorporated to minimize infiltration into the contaminated materials and to optimize ground water protection compliance strategies. Details are site-specific and are available in the RAP for each site.

\subsection{HYDROGEOLOGIC CHARACTERIZATION}

The UMTRA Project conducts investigations at designated uranium processing sites and proposed disposal sites to identify hydrogeologic units, determine hydraulic and transport properties, and identify geochemical conditions. Sufficient data are collected to provide a conceptual hydrogeologic model.

The hydrogeology of both the processing and disposal sites is described. Information on all potentially affected aquifers and confining units is provided, including the geometry, lateral extent, thickness, recharge and discharge zones, and flow characteristics. Uns urated hydrogeologic units that may convey hazardous constituents released from RRM are also identified.

The hydraulic and transport properties of all potentially affected hydrogeologic units at both the disposal and processin? sites are determined based on the hydrogeologic characterization. Hydraulic and transport properties include hydraulic conductivities, storage characteristics, effective porosities, and dispersivities. In addition, the hydraulic gradients, ground water flow directions, and average linear ground water velocities for each potentially affected hydrogeologic unit are described. These descriptions consider the spatial and temporal distribution and isotropy of these properties as appropriate to support compliance demonstrations. 
The material and hydraulic properties of the tailings, contaminated site materials, disposal cell subsoils, and disposal cell cover are determined to evaluate long-term saturation, infiltration, and transient drainage. The information is used to assess whetiner the remedial action will result in compliance with the proposed ground water protection standards.

The geochemical environment within each potentially affected aquifer at the processing and disposal sites is characterized. Hazardous constituents in tailings and RRM are identified, along with the geochemistry and distribution of hazardous constituents in each potentially affected aquifer at the processing sites. Aquifer geochemical characteristics related to contaminant migration at the disposal site are quantified in addition to the geochemical properties of the disposal cell subsoils. Also, the distribution of nonradiological hazardous constituents in subsoils, tailings, and RRM is addressed.

Background and baseline ground water quality of potentially affected aquifers at both the processing and disposal sites is determined. Background ground water quality is established by analyzing samples from one or more monitor wells that are either upgradient or in adjacent areas that have not been affected by uranium processing activities. Baseline ground water quality is determined by analyzing samples from monitor wells located and installed to provide representative characterization of ground water in areas potentially affected by uranium processing activities. Initially, the tailings pore fluids and ground water samples are screened for inorganic and organic hazardous constituents (Table 8.1 of DOE, 1989a). Hazardous constituents may be omitted from further analyses if they meet certain criteria (DOE, 1989a). Ground water monitoring should be conducted for at least 1 year (preferably four sampling periods to note seasonal variations) prior to construction activities. Trends in background and baseline ground water quality for each monitor well are established in the interim between remedial action and the implementation of ground water remediation. Ground water quality data are validated according to DOE level $C$ validation criteria (DOE, 1990b). The TAD provides information on the statistical analyses used to calculate background and baseline concentrations of each hazardous constituent (DOE, 1989a).

A ground water monitoring program starts at each site during the characterization phase and continues through surface remediation and ground water restoration. The ground water monitoring program may phase directly into formal, long-term surveillance once construction is complete. The frequency of ground water sampling is determined based on site-specific factors such as the rate of ground water flow, the possibility of seasonal variations in water quality, and the potential risk to human health and the environment. The results of ground water monitoring are reported in an annual site environmental report as required by DOE Order 5400.1 .

The UMTRA Project requires that existing and potential water sources and uses in the vicinity of disposal and processing sites be identified. Information on the present value of water is established through contact with state agencies, local water companies, and field surveys. In addition, the future value and predicted use 
of regional water resources is determined. Finally, the availability of alternative water supplies is evaluated, including currently used supplies, available but unused supplies, and supplies not currently available but that could be developed.

\subsection{DISPOSAL AND CONTROL OF RESIDUAL RADIOACTIVE MATERIALS}

\subsubsection{Ground water protection strategy}

The DOE will propose a compliance strategy for ground water protection at each UMTRA Project disposal site. The EPA ground water protection standards consist of three components: 1) a list of hazardous constituents, 2) a corresponding list of proposed concentration limits for the constituents, and 3 ) a point of compliance (POC).

Hazardous constituents should satisfy the following two criteria: 1) they must be reasonably expected to be in or derived from the RRM to be stabilized at the site, and 2) they must be constituents listed in the proposed ground water protection standards. The list of hazardous constituents will be based on characterization of the composition of the RRM, ground water quality data, description of the processes and chemicals used in processing uranium, and assessment of whether constituents are reasonably expected to be in or derived from the RRM.

The DOE will propose a concentration limit for each identified hazardous constituent. The concentration limit will be the background concentration for the constituent, the maximum concentration limit, an alternate concentration limit, or supplemental standards.

Where applicable, a POC will be proposed for the disposal site. The POC is a vertical surface that extends downward through the uppermost aquifer along the hydraulically downgradient limit of the disposal cell. Monitor wells will be installed as close to the disposal cell as practical to provide access for monitoring ground water quality without disturbing engineered components of the disposal cell. POC monitoring should provide an early warning of the release of hazardous constituents into the uppermost aquifer.

\subsubsection{Performance assessment}

The DOE will demonstrate to the NRC that the performance of the disposal cells will comply with the ground water protection standard for disposal. For each disposal cell, the DOE will use quantitative analyses of infiltration, leaching, and transport to show that the estimated concentration of each hazardous constituent in ground water in the uppermost aquifer is less than or equal to the proposed concentration limit for that constituent.

\subsubsection{Closure performance assessment}

The DOE will demonstrate compliance with the closure performance standard for each disposal cell. It will show that the need for further maintenance of the 
disposal cell has been minimized and that the disposal cell controls, minimizes, or eliminates releases of hazardous constituents to the ground water to the extent necessary to comply with the ground water protection standard for disposal.

\subsubsection{Ground water monitoring and corrective action planning}

The DOE will describe an integrated ground water monitoring and corrective action program for each disposal site. Ground water (and surface water when applicable) monitoring will be implemented as necessary during and after remediation activities to evaluate the effectiveness of the remedial action, to demonstrate compliance with the EPA ground water protection standards, and to ensure protection of human health and the environment. The ground water monitoring program will consist of baseline, detection, and compliance monitoring. Because ground water contamination problems and remedial action scenarios are site-specific (based on hydrogeologic complexity, magnitude of contamination, and potential impact on human health and the environment), the number and location of monitor wells, analytes evaluated, and sampling frequency will be contingent on site conditions and the selected remedial action. A description of the ground water monitoring program will be presented in the LTSP for each disposal site. The program is reviewed annually, and details of the ground water monitoring to be conducted are identified in site-specific WSAPs.

The ground water monitoring program will also describe statistical procedures and criteria for determining aberrant performances that would trigger analysis and implementation of corrective actions. The DOE will evaluate alternative corrective actions that could be implemented if the disposal monitoring program indicates that a disposal unit is not performing acceptably. The evaluation will demonstrate that corrective actions could be implemented within 18 months to correct reasonable failure scenarios of the disposal cell.

\subsection{GROUND WATER CLEANUP}

The DOE is required to demonstrate that proposed ground water cleanup actions at the UMTRA Project processing sites will bring ground water quality into compliance with the proposed ground water cleanup standards (52 FR 36000). The need for ground water restoration at selected UMTRA Project processing sites is determined based on the EPA regulatory requirements for protection of human health and the environment. A programmatic environmental impact statement, currently being developed in accordance with DOE NEPA procedures, will be used as a planning and decision-making document to determine the program-wide ground water compliance strategy.

To ensure that technically and financially sound ground water restoration activities are selected, the "observational approach" is proposed. The observational approach uses existing site data to develop a conceptual model of site conditions and applicable compliance strategies. This information is used to develop a ground water restoration program based on "most probable" site conditions. The most likely alternative scenarios are also postulated during the development of the initial 
ground water restoration action plan. Contingency plans are developed to deal with deviations from reasonably anticipated conditions. The observational approach links a cost-effective remediation option with an effective contingency plan that will result in full regulatory compliance and protection of human health and the environment without the burden of excessive site characterization and conservatism. 


\subsection{ONGOING ACTIVITIES}

To ensure that the integrity of the permanent disposal cell is maintained and that the cell continues to function as designed, a long-term surveillance program is required by the UMTRCA for each site. This section summarizes the DOE's responsibilities for preparing the site-specific LTSPs, required by the NRC as a condition for licensing under $10 \mathrm{CFR}$ 40.27, and for conducting the long-term surveillance program at disposal sites. Cleanup of contaminated ground water at processing sites is required under the proposed ground water standards (52 FR 36000). This section also summarizes the technical approach to ground water remediation at processing sites.

\subsection{LONG-TERM SURVEILLANCE PLANS}

The DOE prepares detailed site-specific LTSPs in accordance with the NRC licensing regulations in 10 CFR 40.27 . The LTSPs identify and describe the surveillance and monitoring activities required to carry out the long-term surveillance program at the disposal sites. This ensures that the disposal cell continues to function as designed and that the integrity of the disposal site is maintained. The surveillance and. monitoring activities specified in each LTSP become licensing conditions for the disposal site.

The following information will be included in each LTSP:

- A legal description of the disposal site, including documentation of land ownership.

- A detailed description of final site conditions, including existing ground water conditions. The description can be in the form of a reference to an existing document such as a RAP.

- A description of the long-term surveillance program, including the proposed frequency of inspections; the extent of the ground water monitoring network; the frequency of ground water sampling; the appropriate constituents and concentration limits; the inspection procedures and inspection personnel qualifications; the criteria for record keeping and reporting; and procedures for quality assurance.

- The criteria for follow-up inspections in response to observations from routine inspections or to reports of extreme natural events.

- The criteria for instituting maintenance, repair, or corrective action measures.

The ground water performance monitoring is included in the site-specific LTSP in accordance with NRC regulations for the licensing of the disposal sites. The ground water performance monitoring section of an LTSP describes site characterization activities and the water resources protection strategy. In addition, a discussion is provided in the section concerning data validation and quality control, excursion 
criteria, corrective action, additional monitoring requirements, and reporting requirements.

For additional details on the procedures for carrying out the long-term surveillance of ground water at disposal sites, consult the UMTRA Project long-term surveillance program guidance document (DOE, 1992c), LTSPs for each site, and $10 \mathrm{CFR}$ 40.27 .

\subsection{GROUND WATER REMEDIATION ACTIVITIES}

The UMTRA Project has initiated planning for ground water remediation activities (DOE, 1993c). Ground water remediation is to be performed at processing sites where it is deemed necessary to protect human health and the environment. The observational approach is to be applied to ensure that adequate, cost-effective, and technically feasible measures are taken to clean up ground water at the site.

The ground water remediation implementation strategy consists of the following:

- Development of a site observational work plan.

- Site characterization.

- Risk assessment evaluation.

- Interim actions (if required).

- Treatability investigations (if required).

- Selection of ground water remediation method.

- Development of ground water remediation activities.

- Remedial design and implementation.

- Ground water monitoring (as required).

- Demonstration of regulatory compliance.

For further details concerning ground water protection at processing sites, consult the UMTRA Project TAGR (DOE, 1993c). 


\subsection{LIST OF CONTRIBUTORS}

The following individuals contributed to the preparation of this document.

\begin{tabular}{ll}
\hline Name & Contribution \\
\hline A. Vollmer & Overall document coordination \\
R. Heydenburg & Technical content \\
J. Gibb, M. Miller, R. Saar, & Document review \\
C. Yancey & \\
D. Metzler & Peer review \\
D. Thalley & Technical editing \\
E. Bond & Graphics \\
WordCenter Inc. & Text processing \\
\hline
\end{tabular}




\subsection{REFERENCES}

DOE (U.S. Department of Energy), 1993a. UMTRA Project Environmental Protection Implementation Plan, DOE/AL/62350-79, prepared by the DOE UMTRA Project Office, Albuquerque Operations Office, Albuquerque, New Mexico.

DOE (U.S. Department of Energy), 1993b. UMTRA Project Office Quality Assurance Program Plan, DOE/AL/62350-76, Revision 5, prepared by the DOE UMTRA Project Office, Albuquerque Operations Office, Albuquerque, New Mexico.

DOE (U.S. Department of Energy), 1993c. Technical Approach to Groundwater Restoration, DOE/AL/62350-20F, prepared by the DOE UMTRA Project Office, Albuquerque Operations Office, Albuquerque, New Mexico.

DOE (U.S. Department of Energy), 1993d. Guidance Document for Preparing Water Sampling and Analysis Plans for UMTRA Sites, DOE/AL/62350-70F, prepared by the DOE UMTRA Project Office, Albuquerque Operations Office, Albuquerque, New Mexico.

DOE (U.S. Department of Energy), 1992a. UMTRA Project Environmental Monitoring Plan, UMTRA-DOE/AL-150129.0000, prepared by DOE UMTRA Project Office, Albuquerque Operations Office, Albuquerque, New Mexico.

DOE (U.S. Department of Energy), 1992b. UMTRA Project Environmental, Safety, and Health Plan, UMTRA-DOE/AL-150224.0006, prepared by the DOE UMTRA Project Office, Albuquerque Operations Office, Albuquerque, New Mexico.

DOE (U.S. Department of Energy), 1992c. Guidance for Implementing the UMTRA Project Long-term Surveillance Program, UMTRA-DOE/AL-350125.0000, Rev. 1, prepared by the DOE UMTRA Project Office, Albuquerque Operations Office, Albuquerque, New Mexico.

DOE (U.S. Department of Energy), 1990a. UMTRA Project Site Management Manual, UMTRA-DOE/AL-400500.0000, Rev. 1, prepared by the DOE UMTRA Project Office, Albuquerque Operations Office, Albuquerque, New Mexico.

DOE (U.S. Department of Energy), 1990b. Requirements for Quality Control of Analytical Data, DOE/HWP-65/R1, prepared by the U.S. Department of Energy, Hazardous Waste Remedial Actions Program, Oak Ridge, Tennessee.

DOE (U.S. Department of Energy), 1989a. Technical Approach Document, UMTRA-DOE/ AL-050425.0002, prepared by the DOE UMTRA Project Office, Albuquerque Operations Office, Albuquerque, New Mexico.

DOE (U.S. Department of Energy), 1989b. Regulatory Alternatives for Groundwater Compliance for the Department of Energy's UMTRA Project, UMTRA-DOE/AL4000659.0000, prepared by the DOE UMTRA Project Office, Albuquerque Operations Office, Albuquerque, New Mexico. 
DOE (U.S. Department of Energy), 1988. Alternate Site Selection Process for UMTRA Project Sites, UMTRA-DOE/AL-200129.0007, prepared by the DOE UMTRA Project Office, Albuquerque Operations Office, Albuquerque, New Mexico.

DOE (U.S. Department of Energy), 1984. Plan for Implementing EPA Standards for UMTRA Project Sites, UMTRA-DOE/AL-163, prepared by the DOE UMTRA Project Office, Albuquerque Operations Office, Albuquerque, New Mexico.

\section{CODE OF FEDERAL REGULATIONS}

10 CFR 40, "Domestic Licensing of Source Material," Title 10, Code of Federal

Regulations, Part 40, U.S. Nuclear Regulatory Commission, Office of the Federal Register, National Archives and Records Administration, Washington, D.C.

10 CFR 1021, "National Environmental Policy Act Implementing Procedures," Title 10, Code of Federal Regulations, Part 1021, U.S. Department of Energy, Office of the Federal Register, National Archives and Records Administration, Washington, D.C.

40 CFR 192, "Health and Environmental Protection Standards for Uranium and Thorium Mill Tailings," Title 40, Code of Federal Regulations, Part 192, U.S. Environmental Protection Agency, Office of the Federal Register, National Archives and Records Administration, Washington, D.C.

40 CFR 264, Appendix IX, "Groundwater Monitoring List," Title 40, Code of Federal Regulations, Part 264, U.S. Environmental Protection Agency, Office of the Federal Register, National Archives and Records Administration, Washington, D.C.

\section{DOE ORDERS}

Order 5400.1, General Environmental Protection Program, November 8, 1988, U.S. Department of Energy, Washington, D.C.

Order 5440.1E, National Environmental Policy Act Compliance Program, November 10, 1992, U.S. Department of Energy, Washington, D.C.

\section{FEDERAL REGISTER}

52 FR 36000, "Standards for Remedial Actions at Inactive Uranium Processing Sites, Proposed Rule," September 24, 1987, Federal Register, Office of the Federal Register, National Archives and Records Administration, Washington, DC. 


\section{UNITED STATES CODE}

42 U.S.C. $\$ 7901$ et seq. "Uranium Mill Tailings Radiation Control Act of 1978," Title 42, United States Code, Section 7901 et seq., Government Printing Office, Washington, D.C.

42 U.S.C. \$2011 et seq. "Atomic Energy Act of 1954," Title 42, United States Code, Section 2011 et seq., Government Printing Office, Washington, D.C.

42 U.S.C. $\$ 4321$ et seq. "National Environmental Policy Act," Title 42, United States Code, Section 4321 et seq., Government Printing Office, Washington, D.C.

33 U.S.C. $\$ 1251$ et seq. "Clean Water Act," Title 33, United States Code, Section 1251 et seq., Government Printing Office, Washington, D.C.

\section{SITE-SPECIFIC DOCUMENTS}

Site

Ambrosia Lake, New Mexico

Belfield/Bowman, North Dakota

Canonsburg/Burrell, Pennsylvania

\section{Title of Document}

Environmental Assessment - Remedial Action at the Ambrosia Lake Uranium Mill Tailings Site, Ambrosia Lake, New Mexico. Final. DOE/EA-0322. June 1987.

Remedial Action Plan and Site Design for Stabilization of the Inactive Uranium Mill Tailings Site at Ambrosia Lake, New Mexico. Final. UMTRA-DOE/AL-050516.0000. February 1991.

Environmental Assessment of Remedial Action at the Inactive Uraniferous Lignite Processing Sites at Belfield and Bowman, North Dakota. Preliminary Final. DOE/EA-0346. October 1990.

Remedial Action Plan for Stabilization of the Inactive Uraniferous Lignite Processing Sites at Belfield and Bowman, North Dakota. Preliminary Final. UMTRA-DOE/AL-050522. July 1989.

Environmental Impact Statement-Remedial Actions at the Former Vitro Rare Metals Plant Site, Canonsburg, Washington County, Pennsy/vania. Final. DOE/EIS-0096-F. July 1983.

Remedial Action Plan for Stabilization of the Inactive Uranium Mill Tailings Site at Canonsburg, Pennsy/vania. Final. UMTRA-DOE/AL-050501.0140. October 1983. 
Durango, Colorado

Falls City, Texas

Grand Junction, Colorado

Green River, Utah
Surveillance and Maintenance Plan, Canonsburg, Pennsylvania. Final. UMTRA-DOE/AL-350201.0000. July 1992.

Burrell, Pennsylvania, Vicinity Property Long-Term Surveillance Plan. Final. DOE/AL/62350-3F. September 1993.

Environmental Impact Statement - Remedial Actions at the Former Vanadium Corp. of America Uranium Mill Site, Durango, La Plata County, Colorado. Final. DOE/EIS-0111-F. October 1985.

Remedial Action Plan and Site Design for Stabilization of the Inactive Mill Tailings Site at Durango, Colorado. Revised Final. UMTRA-DOE/AL-050503.0000. December 1991.

Remedial Action Plan and Site Design for Stabilization of the Inactive Uranium Mill Tailings Site at Falls City, Texas. Final. UMTRA-DOE/AL-050520.0000. September 1992.

Environmental Assessment of Remedial Action at the Falls City Site, Falls City, Texas. Final. DOE/EA-0468. December 1991.

Environmental Impact Statement - Remedial Actions at the Former Climax Uranium Company Uranium Mill Site Grand Junction, Mesa County, Colorado. Final. DOE/EIS-126-F. December 1986.

Remedial Action Plan and Site Design for Stabilization of the Inactive Uranium Mill Tailings Site at Grand Junction, Colorado. Final. UMTRA-DOE/AL-050505.0000. September 1991.

Environmental Assessment - Remedial Action at the Green River Uranium Mill Tailings Site, Green River, Utah. Final. DOE/EA-0343. July 1988.

Remedial Action Plan and Site Design for Stabilization of the Inactive Uranium Mill Tailings at Green River, Utah. Final. UMTRA-DOE/AL-050510.GRNO. March 1991.

Modifications to the Remedial Action Plan and Site Design for Stabilization of the Inactive Uranium Mill Tailings Site at Green River, Utah. Final. UMTRA-DOE/AL-050510.GRNO, RAP Modification No. 1. February 1992.

Long-Term Surveillance and Maintenance Plan for the Green River, Utah, Disposal Site. Final. September 1992. 
Gunnison, Colorado

Lakeview, Oregon

Lowman, Idaho

Maybell, Colorado

Mexican Hat, Utah
Environmental Assessment of Remedial Action at the Gunnison Uranium Mill Tailings Site near Gunnison, Colorado. Final. DOE/EA-0376. February 1992.

Remedial Action Plan and Site Design for Stabilization of the Inactive Mill Tailings Site at Gunnison, Colorado. Final. UMTRA-DOE/AL-050508.0000. October 1992.

Environmental Assessment of Remedial Action at the Lakeview Uranium Mill Tailings Site, Lakeview, Oregon. Final. DOE/EA0271. April 1985.

Remedial Action Plan and Site Conceptual Design for Stabilization of the Inactive Uranium Mill Tailings Site at Lakeview, Oregon. Final. UMTRA-DOE/AL-050510.0000, Rev 1. July 1992.

Long-Term Surveillance Plan for the Lakeview, Oregon, Disposal Site. Final. UMTRA-DOE/AL-350213.0000. September 1992.

Environmental Assessment of Remedial Action at the Lowman Uranium Mill Tailings Site, Lowman, Idaho. Final.

DOE/EA-0353. January 1991.

Remedial Action Plan and Site Design for Stabilization of the Inactive Uranium Mill Tailings Site at Lowman, Idaho.

UMTRA-DOE/AL-050512.0000. Final. September 1991.

Long-Term Surveillance Plan for the Lowman, Idaho, Disposal Site. Preliminary Final. DOE/AL/62350-36PF. September 1993.

Environmental Assessment of Remedial Action at the Maybell Uranium Mill Tailings Site near Maybell, Colorado. DOE/EA0347. September 1993.

Remedial Action Plan and Site Design for Stabilization of the Inactive Uranium Mill Tailings Site, Maybell, Colorado.

Preliminary Final. DOE/AL/62350-24PF. June 1993.

Environmental Assessment of Remedial Action at the Mexican Hat Uranium Mill Tailings Site, Mexican Hat, Utah. Final. DOE/EA-0332. October 1987.

Remedial Action Plan for the Codisposal and Stabilization of the Monument Valley and Mexican Hat Uranium Mill Tailings at 
Monumerit Valley, Arizona

Naturita, Colorado

Rifle, Colorado

Riverton, Wyoming

Salt Lake City, Utah
Mexican Hat, Utah. Final. UMTRA-DOE/AL-050509.000.

February 1993.

Environmental Assessment of Remedial Action at the Monument Valley Uranium Mill Tailings Site, Monument Valley, Arizona. Final. DOE/EA-0368. June 1989.

Remedial Action Plan for the Codisposal and Stabilization of the Monument Valley and Mexican Hat Uranium Mill Tailings at Mexican Hat, Utah. Final. UMTRA-DOE/AL-050509.000.

February 1993.

Environmental Assessment of Remedial Action at the Naturita Uranium Processing Site near Naturita, Colorado. DOE/EA. 0464, Rev. 1. August 1993.

Remedial Action Plan and Site Design for Stabilization of the Inactive Uranium Processing Site at Naturita, Colorado.

Preliminary Final. DOE/AL/62350-4OPF. August 1993.

Environmental Impact Statement - Remedial Actions at the Former Union Carbide Corporation Uranium Mill Sites, Rifle, Garfield County, Colorado. Final. DOE/EIS-0132-F. March 1990.

Remedial Action Plan and Site Conceptual Design for Stabilization of the Inactive Uranium Mill Tailings Site at Rifle, Colorado. Final. UMTRA-DOE/AL-050506.0000. August 1991.

Environmental Assessment - Remedial Action at the Riverton Uranium Mill Tailings Site. Final. DOE/EA-0254. June 1987.

Remedial Action Plan and Site Design for Stabilization of the Inactive Uranium Mill Tailings Site at Riverton, Wyoming. Final. UMTRA-DOE/AL-050507.0000. October 1987.

Environmental Impact Statement - Remedial Actions at the Former Vitro Chemical Company Site, South Salt Lake, Salt Lake County, Utah. Final. DOE/EIS-0099-F. July 1984.

Remedial Action Plan and Site Conceptual Design for Stabilization of the Inactive Uranium Mill Tailings Site at Salt Lake City, Utah. Final. UMTRA-DOE/AL-050502.0141. December 1984. 
Shiprock, New Mexico

Slick Rock, Colorado

Spook, Wyoming

Tuba City, Arizona
"Surveillance and Maintenance Plan, South Clive Disposal Site, Utah." Draft. UMTRA-DOE/AL-350202.0000. Febjuary 1987.

Environmental Assessment of Remedial Action at the Shiprock Uranium Mill Tailings Site, Shiprock, New Mexico. Final. DOE/EA-0232. May 1984.

Remedial Action Plan and Site Conceptual Design for Stabilization of the Inactive Uranium Mill Tailings Site at Shiprock, New Mexico. Final. UMTRA-DOE/AL-050504.0039. June 1985.

Long-Term Surveillance Plan for the Shiprock, New Mexico, Disposal Site. UMTRA-DOE/AL-350204.0000. January 1993.

Environmental Assessment of Remedial Action at the Slick Rock Uranium Mill Tailings Sites, Slick Rock, Colorado. Draft. DOE/EA-0339. June 1993.

Remedial Action Plan and Site Design for Stabilization of the Inactive Uranium Mill Tailings Sites at Slick Rock, Colorado. Draft. DOE/AL/62350-21D. July 1993.

Environmental Assessment of Remedial Action at the Spook Uranium Mill Tailings Site, Spook, Wyoming. Final.

DOE/EA-0345. April 1989.

Remedial Action Plan and Site Conceptual Design for Stabilization of the Inactive Uranium Mill Tailings Site at Spook, Wyoming. Final. UMTRA-DOE/AL-050515.0000. July 1989.

Long-Term Surveillance Plan for the Spook, Wyoming, Disposal Site. Final. UMTRA-DOE/AL-350215.0000. January 1993.

Environmental Assessment - Remedial Action at the Tuba City Uranium Mill Tailings Site, Tuba City, Arizona. DOE/EA-0317. Final. DOE/EA-0317. November 1986.

Remedial Action Plan and Site Design for Stabilization of the Inactive Uranium Mill Tailings Site at Tuba City, Arizona. Final. UMTRA-DOE/AL-050518.0000. August 1989.

Long-Term Surveillance Plan for the Tuba City, Arizona, Disposal Site. Final. UMTRA-DOE/AL-350218.0000. December 1992. 

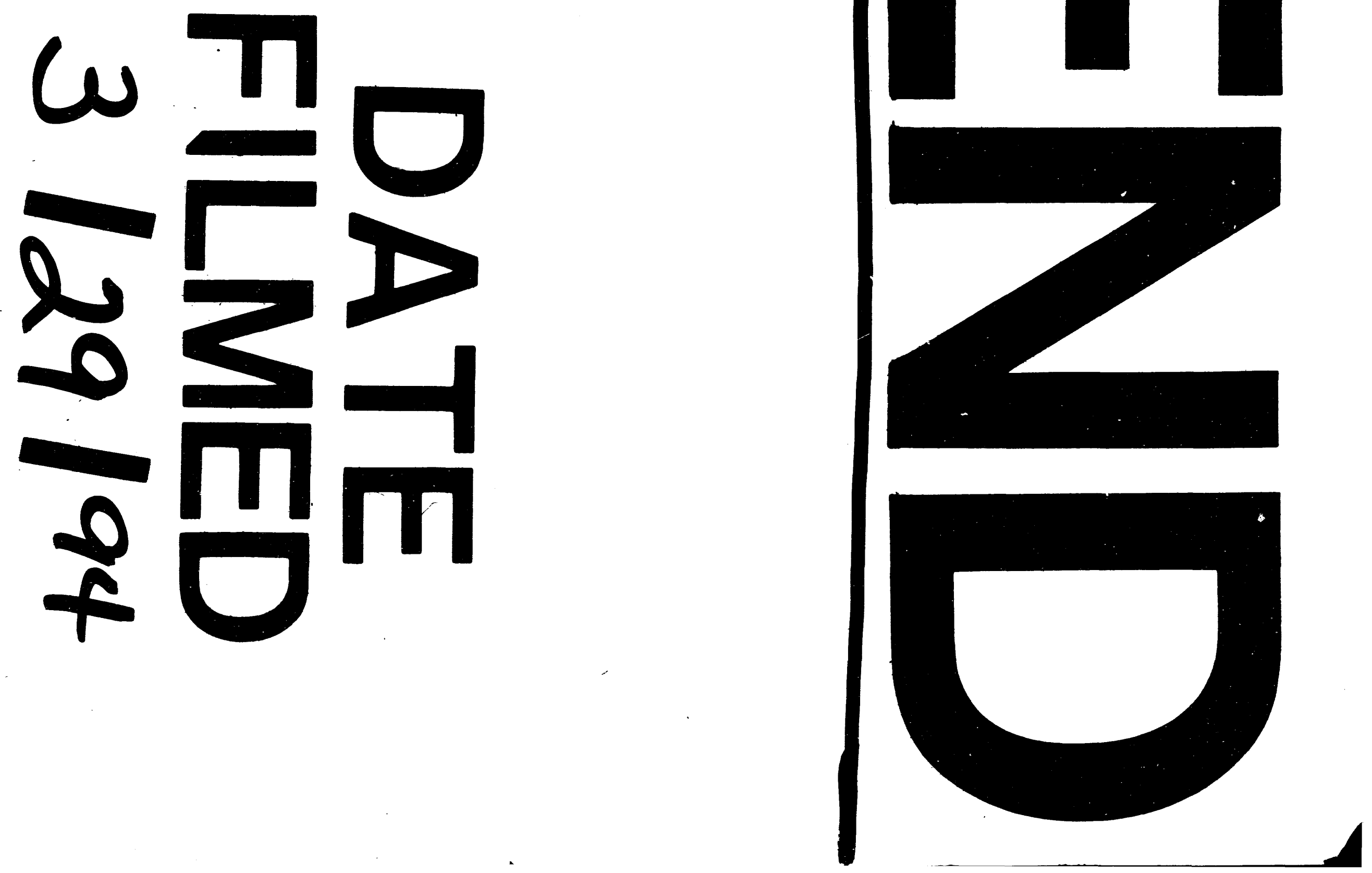


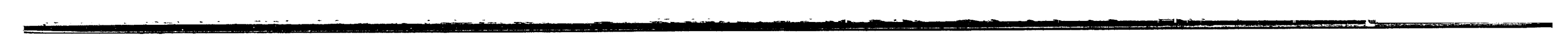

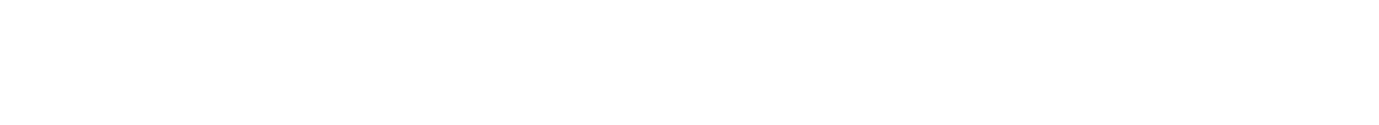
(1)

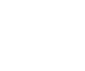

